2018

\title{
Why Are We Doing Math in English Class? Building Quantitative Literacy to Improve Expository Text Comprehension
}

Ellen C. Agnello

University of Connecticut, ellen.cavanaugh@uconn.edu

\section{Recommended Citation}

Agnello, Ellen C.. "Why Are We Doing Math in English Class? Building Quantitative Literacy to Improve Expository Text Comprehension." Numeracy 11, Iss. 2 (2018): Article 4. DOI: https://doi.org/10.5038/ 1936-4660.11.2.4 


\title{
Why Are We Doing Math in English Class? Building Quantitative Literacy to Improve Expository Text Comprehension
}

\begin{abstract}
In 2009, The Common Core Standards shifted the English language arts focus from narrative to expository text, arguing that most texts read in college and workforce training programs are informational. By the time students are in twelfth grade, they are expected to read informational text $70 \%$ of the time. This can be challenging for English teachers if their students lack the skills needed to navigate the features of these more challenging texts. Graphs, tables, and charts detract from the readability of informational text when students lack quantitative literacy and numeracy skills. This article provides practical applications for teaching quantitative literacy in the language arts classroom through the execution of a writing workshop-based survey-inquiry project. The goal is that through experimentation with statistics obtained through collecting and analyzing their own sample of survey data, students will develop a more concrete understanding of statistics and become more proficient readers of complex expository texts.
\end{abstract}

\section{Keywords}

quantitative literacy, english, language arts, reading comprehension, expository text, text complexity, numeracy, new literacies, 21 st century skills, common core state standards, process writing, table interpretation, data visualizations

\section{Creative Commons License}

\section{c) (7) (8)}

This work is licensed under a Creative Commons Attribution-Noncommercial 4.0 License

\section{Cover Page Footnote}

Ellen Agnello is a doctoral student in reading education at the University of Connecticut. She holds an M.Ed from Providence College and a B.A. in English from Connecticut College. She is certified by the state of Connecticut to teach secondary English language arts and reading. Previously, she taught English language arts for seven years, which inspired her to return to school to study reading, text complexity, and comprehension strategy instruction. She is interested in how mathematical representations increase expository text complexity and how teachers can model strategies to facilitate their students' comprehension of expository texts. 


\section{Introduction}

\section{The Case for Quantitative Literacy Instruction in the English Language Arts Classroom}

The ninth-grade students in my first-period English class had just read a challenging news article on heroin use. We were studying The Odyssey, and I wanted to elucidate the epic's allegory by having students connect Book 9, in which the men become hypnotized after consuming the intoxicating lotus fruit, to modern opioid addiction. I said:

Question number five. According to the article, who is the average heroin user?

My students' vacant stares suggested that maybe I was speaking a foreign language.

Although the ninth-grade English curriculum was literature heavy, my department head requested that we implement as much expository text as possible to meet the new demands of the Common Core State Standards. This request posed a fresh set of challenges for my reluctant readers and me.

Okay, let's look back at the text. It says, 'Eighty-eight percent of those who died from heroin were white, half were younger than 34, and almost a fifth were ages 15 to 24 .' Now let's see if we can answer that question: 'Who is the average heroin user?'

Still, not a single hand was raised and not a single eye lit up indicating an inkling of an idea. Before I could get to the root of my students' difficulty, the bell rang and they were off.

By fifth period, I was almost ready to give up. I failed to elicit any inferences from my four previous classes and knew that the next would be more of the same.

With energy gained from my twenty-minute lunch, I tried a new approach. I cautioned my students,

To answer question five, we need to look at some of these numbers. The author tells us that ' 88 percent ... were white.' Is that a lot or a little?

No hands went up. I waited.

One student hesitantly offered,

A little...?

Finally, it all made sense. My students couldn't infer the answer because they couldn't penetrate into the layers of meaning the statistics provided. The more I probed, the more I found that their lack of quantitative literacy was making it impossible for them to access information in the text. To make these texts more accessible, I knew that I had to teach my students how to read, write, and talk about numbers. But how could I, without completely derailing from my required English language arts (ELA) curriculum and the Common Core State Standards? 


\section{The Problem}

Although the Common Core State Standards encourage teachers to shift their focus from narrative to expository text, they don't explain how doing so also necessitates a shift in cognitive demands or pedagogy. Teachers may not recognize the major differences in mental processes that the two types of text require. Expository text poses greater challenge to students because of the various text features associated with it. In addition to technical vocabulary, most expository texts include several modes of representation, including numbers, graphs, diagrams, tables, charts, and pictures (Lemke 1998). These diverse features require that students interpret meaning across multiple symbol systems rather than written text alone (Lemke 1998). In addition to basic reading comprehension strategies, this expansion requires mastery of processes not traditionally taught in the English language arts classroom, such as a functional knowledge of mathematical content and an ability to reason mathematically (Wilkins 2000). Prior to asking students to comprehend an expository text, teachers must assess it for the number of symbol systems present and consider whether students have the necessary knowledge to interpret the information available to them (Lemke 1998). Unless students have a solid working quantitative literacy, their ability to comprehend such texts becomes compromised.

\section{What is Quantitative Literacy?}

Quantitative Literacy (QL) is one of many responses to late-20 $0^{\text {th }}$ century calls for educational reform (Wilkins 2000). Influential reports such as $A$ Nation at Risk (Gardner et al. 1983), Mathematics Counts (Cockroft 1982), and Everybody Counts (National Research Council 1989), demanded that schools prepare students to enter our data-saturated society and navigate it successfully. Following the publication of these reports, many conceded that QL is important, but disagreement remains as to what skills are required for one to be considered quantitatively literate (Forman and Steen 1999). In fact, few have agreed upon a label to signify the skills required by QL. Numeracy, statistical literacy, mathematical thinking, and scientific literacy have been used interchangeably to connote a similar skill set (Karaali et al. 2016). Most of the definitions in circulation agree that, as literacy is more than a basic familiarity with letters, QL involves much more than the ability to recognize numbers (Karaali et al. 2016). Instead, quantitatively literate individuals must be able to identify the implications of mathematical representations as they appear in the texts that they encounter daily (National Research Council 1989). Variations among classic definitions of QL include:

- The ability to apply general world knowledge and basic mathematics to make reasoned decisions in daily life situations (Wiest et al. 2007).

- The application of advanced reasoning with basic mathematics to real world contexts (Steen 2004). 
- Possession of a working knowledge of math content, an ability to reason mathematically, a recognition of the potential societal impact and use of mathematics, an understanding of the nature of mathematics, and a positive attitude towards mathematics (Hughes Hallett 2003).

Although QL is often perceived to be aligned with the mathematics curriculum, it is rarely taught in the math classroom (Steen 2001). In the elementary and intermediate grades, basic numeracy (meaning number skills) is the curricular focus. Once students enter the higher grades, the focus shifts to traditional mathematics, such as algebra (Steen 2001). Little time is left for teaching students to apply their mathematical knowledge to real-world contexts.

While it involves skills related to those taught in the math classroom, QL is inherently interdisciplinary (Steen 2001) because it is embedded in social and cultural life. The need for QL presents itself in every subject area, including science, language arts, history, fine arts (Steen 2001), and even culinary arts.

The problem is that QL is scarcely being taught, and QL skills are not mentioned in The Common Core State Standards for English Language Arts. For instance, although the Standards articulated on the Common Core website require twelfth graders to read informational text $70 \%$ of the time, they make no mention of having the ability to interpret data or statistics in those texts. The Next Generation Science Standards, described on the National Science Teachers Association website, have attempted to combat the lack of QL by introducing students to data analysis skills as early as kindergarten. However, as of December 2016, only 19 states had adopted these more rigorous learning standards.

Although students aren't learning QL skills in their ELA classrooms, they are held accountable for them by high-stakes tests. Currently six states, including Connecticut, require students to take the SAT prior to graduation. As described on the College Board website, the SAT was redesigned in 2016 to incorporate $21^{\text {st }}$ century skills such as analyzing data and informational graphics, such as tables, graphs, and charts, in conjunction with text.

\section{The Importance of Quantitative Literacy}

In the past, literacy and mathematics seemed to share nothing in common. Scholars today argue not only that the domains overlap but that literacy skills should be taught in the math classroom and numeracy skills in the language arts classroom (Schoenfeld 2001). Now more than ever, it is important to teach QL in every subject. Our world is becoming increasingly quantified as data has become the most privileged mode of communication (Shreiner 2017). It was long believed that citizens needed verbal literacy to protect against ignorance; however, now that our society depends largely on quantitative measures to present patterns and trends in current issues, it is also imperative to have a solid basis of QL to make informed decisions and engage in the democratic process (Steen 1999). Understanding nearly 
every major public issue, such as health care, the opioid epidemic, and police brutality depends on a solid basis of QL. Even minor, day-to-day personal issues, such as which foods to avoid when trying to lower cholesterol or which loan has the best interest rate, presents citizens with data and the need to interpret it to make the best decision. If the goal of education is to provide students with the skills needed to become active participants in society, then QL needs to be emphasized.

But how can teachers, particularly those of adolescent, struggling readers, authentically deliver QL instruction in the language arts classroom without compromising their curriculum or adherence to the Common Core Standards? The remaining sections of this article will illustrate how one assignment was useful in generating QL in adolescent, reluctant readers. At the same time, it will provide a practical, replicable approach for embedding QL instruction into a highly engaging inquiry project.

\section{Using The Inquiry-Survey Project in ELA to Teach QL Skills}

Many of us have encountered student resistance to expository texts. However, before abandoning them entirely, we must consider which factors increase their difficulty. For instance, do they contain mathematical representations like percentages, graphs, and tables? Do our students have the QL skills necessary to identify and draw inferences from the embedded statistics and data visualizations? If not, it is our responsibility to build their numeracy within the contexts of reading and writing.

But shouldn't the math teacher teach those skills?

Yes, but we should, too. If it is our job as ELA teachers to show students how to draw inferences from literary devices in fiction, it should also be our responsibility to teach them to identify numbers in expository text and to similarly draw logical conclusions from them.

It seems simple enough. However, what if our students lack the QL skills needed to draw those conclusions? For instance, what if they aren't able to access the layers of meaning implied by " $50 \%$ "?

Like anything else, students will need explicit teaching and an authentic learning context to assimilate the necessary QL skills. After discovering that my ninth-graders were struggling to read expository text for this very reason, I used The Inquiry-Survey Project to help build their QL skills by practicing data and text integration.

I called it "The Inquiry-Survey Project" because I wanted my students to generate a provocative question, and investigate it by surveying their peers or teachers. Doing so would provide students with an authentic context to produce their own data and make inferences about a population based on the results. I felt 
that my students would best internalize QL skills by immersing them in the process of generating data, calculating percentages, and writing and speaking about their findings.

The purpose of the project was twofold. Through it, I wanted to expand my students' QL schemata so that, in the future, they could better comprehend expository text containing a variety of mathematical representations. To my students and head of department, however, I framed it as a writing assignment because I knew that they wouldn't immediately understand my decision to spend several classes on a project that more closely resembled math than English.

The Inquiry-Survey Project spanned six classes and included the following steps:

1. Brainstorming: Identifying potential participants, topics, and questions for surveys.

2. Survey Creation: Using Google Docs to build and format surveys.

3. Survey Administration: Soliciting peers and teachers to take surveys.

4. Tallying the Results: Organizing survey data and calculating percentages.

5. Making Conclusions: Writing conclusion statements based on survey results.

6. Presenting Findings: Using words, images, and mathematical representations to share conclusions

\section{Class 1: Brainstorming}

On the first day of the project, I stood in front of my ninth-graders and announced,

For our next unit, we are going to investigate a population. You are going to find out how that population feels about a topic of interest to you. To do so, you'll each create a survey, distribute it, and analyze the results. In the end, we'll share our findings.

Although these directions seemed transparent enough to me, my students' questions suggested otherwise. They wanted to know who they could survey, when and where they could administer the surveys, and what questions to ask.

To harness their excitement and help them organize their ideas to create cohesive surveys, I used elements of the Writing Workshop process. Writing Workshop is a process that provides students with choice, collaboration, explicit instruction, and the freedom to progress at their own pace. Rather than assigning inquiry topics, I engaged them in a brainstorm of potential writing territories. Atwell (2002) explains that writing territories consist of a range of things that authors do, such as considering potential subjects, audiences, and genres prior to writing. Atwell (2002) likens writing territories to a bank of ideas, explaining that writers can always return to them if a particular topic doesn't pan out.

Before releasing responsibility to my students, I shared my writing territories with them. In my list (Table 1), I tried to include provocative and compelling topics that would, in my students' minds, conjure images of themselves investigating a 
serious and relevant issue (Atwell 2002). Prior to class, I hand-wrote my ideas in a notebook so that I could project them, using a document camera, for the entire class to see. This could just as easily have been done by recording topics on the black/white board.

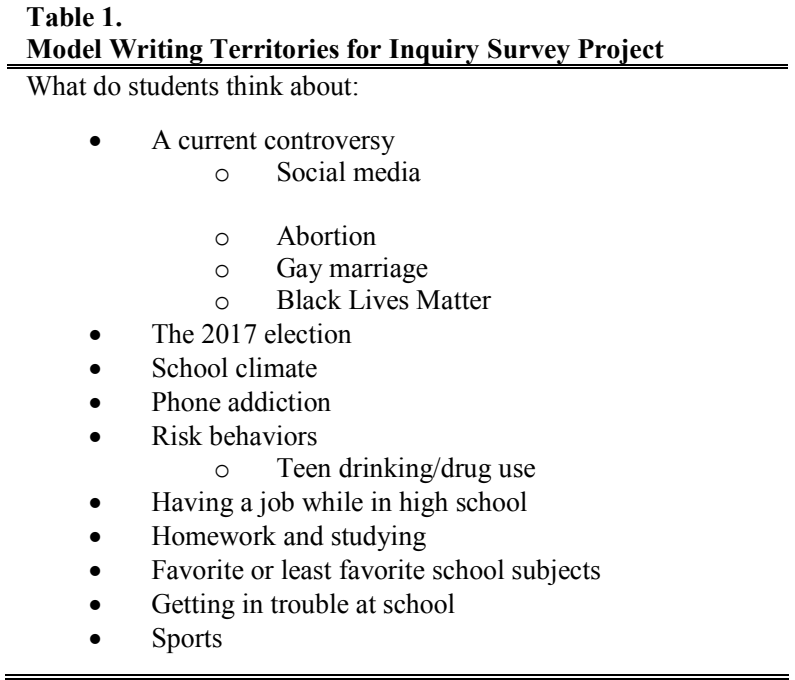

To make my thinking explicit, I spent several minutes thinking-aloud about my topics, explaining my curiosities, hypotheses, and reasons for selecting each. For instance, when discussing, "phone addiction," I explained:

As I brainstormed, I thought about what my goal might be, who I would have to survey, and what I would have to ask to accomplish it.

I continued,

For each of these topics, I could perform my investigation from several angles to accomplish different goals. Let's look at phone addiction. I could compare students' thoughts on whether cell phones interfere with academics to their teachers' thoughts. I could compare freshman to senior cell-phone use to see if it increases or decreases over time. I could also hypothesize that students aren't even aware of how dependent they are on their phones and how much their phones interfere with their learning. To do so, I could start my survey by asking, "Are you addicted to your cell phone?" Then, I could ask questions about their cell phone habits to see if their responses align.

After sharing my thinking for each of the writing territories, I gave my students seven minutes to brainstorm theirs. I projected a timer on the board and asked them to work quietly in their writer's notebook until the time was up. I suggested that they record as many topics as possible and gave them the goal of ten. As they worked, I circulated around the room to confer with students and assist those who appeared to be stuck. 
Choosing Five Possible Topics. At the end of the seven minutes, I announced,

Time's up. If you weren't able to come up with ten topics, that's okay. On a new page in your writer's notebook, list your five favorite topics. Be sure to leave room next to each so that a partner can record notes.

By the end of the brainstorm, some students had recorded only one topic whereas others had fifteen or more. Students who needed an additional scaffold borrowed some topics from my demonstration of writing territories. Regardless of the quantity and quality of topics, all students flipped to a new page and recorded no more than five favorites.

Partner Brainstorm 1. Once it seemed as though all students had finished recording their topics, I explained,

With the help of a partner, we're going to narrow down our focus and select our survey topics.

The purpose of the first partner brainstorm is to help students identify the topic, among their list of five, that is most interesting and substantial. Students work with a partner in two distinct roles. By explicitly modeling these roles, students are better prepared to engage in a productive discourse about their topics.

I enlisted a student, Naomie, to be my partner for the model. I projected her writer's notebook on the board and asked her to tell me about her topics, emphasizing what made her curious about them, who she thought she might survey, and why. As she spoke, I recorded questions in her writer's notebook. These initial thoughts later became inspiration for her survey questions. Once finished, I read my questions to her and told her which topic I felt had the most potential. I emphasized, however, that the final decision was hers. Table 2 consists of a transcript of that first partner brainstorm.

Following the model, I released the responsibility to the class. They selected their own partners and had fifteen minutes to discuss their topics, curiosities, and goals and to receive feedback and narrow down their topic choices.

Once all were finished, we took turns sharing our topics out loud. At this stage, not all students were completely decided. Rather than sharing a topic, these students shared all of the topics still under consideration and elicited votes from their classmates.

Selecting a Topic. After my students proudly proclaimed their topic choices, they were ready to move on to the next step. To introduce it, I said,

On a new page in your writer's notebook, record your topic. Underneath it, list the questions that your partner came up with during the first partner brainstorm. If you can think of others, list those too.

Initially, most students had no more than five questions. For a full investigation of our chosen topics and populations, we were aiming for more than seven. More than 
Table 2.

Transcript of Partner Brainstorm 1

\begin{tabular}{|c|c|c|}
\hline Topics & Naomie Said & My Questions \\
\hline Relationships & $\begin{array}{l}\text { I want to know how many } \\
\text { students are in relationships } \\
\text { or have been in the past. I } \\
\text { want to know how long their } \\
\text { relationships last and why } \\
\text { they end. }\end{array}$ & $\begin{array}{l}\text { - Who will you survey? } \\
\text { - Will you compare students' and teachers' responses or } \\
\text { freshmen' and seniors'? } \\
\text { - Do your parents allow you to date? } \\
\quad \text { Does your relationship interfere with school? }\end{array}$ \\
\hline Bullying & $\begin{array}{l}\text { I want to find out how many } \\
\text { students have been bullied in } \\
\text { the past and why. }\end{array}$ & $\begin{array}{l}\text { - } \quad \text { Have you been bullied in person or online? } \\
\text { - } \quad \text { Did you report the incident? } \\
\text { - } \quad \text { Did you know the bully? }\end{array}$ \\
\hline School schedule & $\begin{array}{l}\text { I want to see how students } \\
\text { feel about the new schedule } \\
\text { and if they have any ideas } \\
\text { for improving it. }\end{array}$ & $\begin{array}{l}\text { - } \quad \text { Do you think classes are too short or too long? } \\
\text { - Should we have a 9-minute homeroom every day? } \\
\text { - Should we go to school year-round? }\end{array}$ \\
\hline Clothing & $\begin{array}{l}\text { I want to find out what } \\
\text { students wear and if brands } \\
\text { are important to them. }\end{array}$ & $\begin{array}{l}\text { - } \quad \text { Do you pay attention to what brands your friends wear? } \\
\text { - } \quad \text { How much are you willing to spend on a pair of new shoes? } \\
\text { - Do your friends tease you if/when you wear certain brands? }\end{array}$ \\
\hline Risk behaviors & $\begin{array}{l}\text { I want to see if students are } \\
\text { drinking or doing drugs. If } \\
\text { they are, I want to know } \\
\text { when they started and why. }\end{array}$ & $\begin{array}{ll}\text { - } & \text { Do you smoke? } \\
\text { - } & \text { Do you drink? } \\
\text { - } \quad \text { Do your friends encourage you to smoke or drink? } \\
\text { Does your family encourage you to smoke or drink? }\end{array}$ \\
\hline
\end{tabular}

twenty, however, might overwhelm our participants. I encouraged students not to worry if they had fewer than seven questions because the rest would come during the second partner brainstorm.

Partner Brainstorm 2. I explained to students,

The purpose of the second partner brainstorm is to help us come up with the rest of our survey questions.

Again, I modeled the process prior to releasing the responsibility to my students. I had a new student volunteer, Yuridia, give me her writer's notebook and share her topic and questions. As she spoke, I added as many questions as I could to her list. Once finished, I shared the new questions with her and explained why I added them. Table 3 displays a sample of a writer's notebook after the second partner brainstorm.

After modeling the second partner brainstorm, I gave students another 15 minutes to choose a new partner and engage in the process themselves. I circulated providing support to students who struggled to come up with additional questions for their partner. At the end of class, most students had established the bones of their surveys.

\section{Class 2: Creating our Surveys}

I started our second class by explaining,

Now that we have our questions, we're ready to create our surveys. 
Table 3.

Using Partner Brainstorm 2 to Generate More Questions

\begin{tabular}{|c|c|}
\hline Yuridia's Questions & My Questions \\
\hline Are you addicted to your phone? & How long do you spend on your phone? \\
\hline Do you have a smartphone? & - How often do you check your phone in class? \\
\hline Do you check your phone in between classes? & - Why do you check your phone during school? \\
\hline $\begin{array}{l}\text { 4. Do you know what the school policy on cell } \\
\text { phone use is? }\end{array}$ & - Do your teachers let you? \\
\hline $\begin{array}{l}\text { 5. Do you use your phone to listen to music } \\
\text { during class? }\end{array}$ & - Which ones? \\
\hline 6. Do you use social media apps during school? & Do you feel lost without your phone? \\
\hline $\begin{array}{l}\text { 7. Do you use your data to check your phone } \\
\text { during school? }\end{array}$ & - Do you feel depressed or anxious without your \\
\hline Do you charge your phone during class? & \\
\hline $\begin{array}{l}\text { 9. Do you go to the bathroom to check your phone } \\
\text { during school? }\end{array}$ & \\
\hline
\end{tabular}

Students used Google Docs to do so. They typed their questions and response items and added titles and brief directions. I showed them how to use different features of Google Docs, such as how to insert a table to make their surveys more visually appealing and accessible. Once finished, they shared their documents with me so that I could print copies for them to distribute. Figure 1 shows a survey similar to those created by my students after finishing the second partner brainstorm.

\begin{tabular}{|c|c|c|c|c|c|c|}
\hline \multicolumn{7}{|c|}{$\begin{array}{l}\text { Inquiry-Survey: Relationships } \\
\text { Read the question below and circle your answer. }\end{array}$} \\
\hline What grade do you teach? & 9th & 10th & 11th & 12th & \multicolumn{2}{|c|}{ More than one } \\
\hline \multicolumn{5}{|c|}{ 1. Do you agree with students having relationships in school? } & Yes & No \\
\hline \multicolumn{5}{|c|}{ 2. Are students' relationships distractions in school? } & Yes & No \\
\hline \multicolumn{5}{|c|}{ 3. Do your students talk to you about their relationships? } & Yes & No \\
\hline \multicolumn{5}{|c|}{ 4. Do your students put their relationships before school work? } & Yes & No \\
\hline \multicolumn{5}{|c|}{ 5. Do students bring relationship drama into class? } & Yes & No \\
\hline \multicolumn{5}{|c|}{ 6. Are students' relationships ever positive/healthy? } & Yes & No \\
\hline \multicolumn{5}{|c|}{ 7. Do you think it's appropriate when students hug and kiss in the hallway? } & Yes & No \\
\hline \multicolumn{5}{|c|}{$\begin{array}{l}\text { 8. Do you ever catch your students leaving class to see their } \\
\text { boyfriends/girlfriends? }\end{array}$} & Yes & No \\
\hline \multicolumn{5}{|c|}{ 9. Do your students' relationships ever disrupt classroom learning? } & Yes & No \\
\hline \multicolumn{5}{|c|}{ 10. Do your students' relationships ever make it hard for your to do your job? } & Yes & No \\
\hline
\end{tabular}

Figure 1. A sample survey. Surveys were created on Google Docs. Students inserted tables to organize their questions and answer options. 


\section{Class 3: Survey Administration}

Prior to our third class, I printed 25 copies of each student's survey. I placed the copies in manila folders and labelled them with my students' names. As my students entered the classroom, I presented them with their folders. Their excitement in response to the sight of their work would have made more sense had I been distributing Christmas gifts. As they settled down, I announced,

Today is the day! You will have almost the full class period to survey your peers and teachers. You can go anywhere on campus to do so. Be sure to come back with all 25 completed. And whatever you do...PLEASE don't lose them!

I strategically planned for this activity to fall during lunch periods so that students could survey their peers and faculty in the cafeteria. Some students also chose to visit the library, study halls, and PE classes. Most were excited to engage in this part of the process, and almost every student returned with all surveys completed.

\section{Class 4: Tallying the Results and Calculating Percentages}

This class marked the true beginning of our work. Karazsia (2013) asserts that an active learning strategy in which students create and manipulate their own tables will help them better interpret tables when they encounter them in texts. This strategy is more beneficial than explicitly teaching table interpretation because it facilitates active engagement with the material (Karazsia 2013). In line with this hypothesis, my hope was that by teaching students to calculate percentages using their own data, they would be better able to interpret percentages encountered in expository texts (Karazsia 2013). The fourth class thus focused on computation. I declared,

Here comes the hard part. You might think I'm crazy when I say this next bit, but...today we're going to do some math in English.

We started the class by creating tally sheets. I guided students through the process by opening my original survey in Google Drive, deleting the response items, and expanding the columns to accommodate for future tally marks. See Figure 2 for a sample tally sheet.

Students followed along on individual Chrome Books. Once finished, I printed their tally sheets and modeled the process of using tally marks to signify survey responses with my own data set. I showed them, for example, how to represent five responses by drawing a line through four tally marks and explained that doing so would make it easier to see the final count. 


\begin{tabular}{|c|c|c|c|c|}
\hline & & \multicolumn{2}{|c|}{ YES } & No \\
\hline \multicolumn{5}{|l|}{ 2. Do you have a phone? } \\
\hline \multicolumn{5}{|l|}{ 3. Are you addicted to it? } \\
\hline \multicolumn{5}{|l|}{ 4. Do you check your phone during class? } \\
\hline \multicolumn{5}{|c|}{ 5. Do you use social media apps like Facebook, Snapchat, and Instagram during school? } \\
\hline \multicolumn{5}{|c|}{ 6. Do you use your data to check your phone during schooll } \\
\hline \multicolumn{5}{|c|}{ 7. Do you charge your phone during school? } \\
\hline \multicolumn{5}{|c|}{ 8. Do you go to the bathroom to check your phone without getting in trouble? } \\
\hline \multicolumn{5}{|c|}{ 9. Have you received a consequence (detention, etc.) because of your phone? } \\
\hline \multicolumn{5}{|c|}{ 10. Do you know what the cell phone policy is, but still break it? } \\
\hline & $0-1 \mathrm{hr}$ & $2-3 \mathrm{hrs}$ & 4.5 hrs & $5+$ hrs \\
\hline \multicolumn{5}{|c|}{ 11. How much time do you spend on your phone each day? } \\
\hline & Text/SM & Videos & Games & Other \\
\hline \multicolumn{5}{|l|}{ 12. What do you do while on your phone? } \\
\hline & Insta & $\mathrm{SC}$ & FB & Twitter \\
\hline \multicolumn{5}{|c|}{ 13. Which social media app do you use the most? } \\
\hline & $0-1 \mathrm{hr}$ & $2-3 \mathrm{hrs}$ & 4-5 hrs & $5+$ hrs \\
\hline \multicolumn{5}{|c|}{ 14. How much time do you spend studying/doing homework each day? } \\
\hline & A's & B's & C's & $D^{\prime} s / F^{\prime} s$ \\
\hline 15. What grade do you get on average? & & & & \\
\hline
\end{tabular}

Figure 2. Inquiry survey tally sheet. To create tally sheets, students deleted the answer options from their surveys and expanded columns to accommodate for tally marks.

The process of tallying results proved to be extremely difficult. As my students attempted to work independently, they consistently lost their places and made errors that compromised their data. To remedy this problem, I instructed them to switch their results with a partner and have their partner read the survey responses aloud: " 1 is yes, 2 is yes, 3 is no, 4 is yes, 5 is no, 6 is yes." This procedure would help the students keep track of their tallies without having to look back and forth between two sheets. After all students finished tallying their results, I told them to add up the tally marks for each response. I also cautioned them to check that all twenty-five of their responses were accounted for by totaling the tally marks for each question.

I distributed calculators and showed students how to calculate percentages for each question by dividing the number of tallies for each response by the total number of survey responses. Then, I showed them how to convert the decimal to a percentage by moving the decimal two spaces to the right. As students worked, they recorded the percentages on their tally sheets. I circulated to aid those who needed help. 


\section{Class 5: Making Conclusions from and Writing About Percentages}

According to Beins (1993), writing about statistics improves students' computational and interpretive skills more so than traditional statistics instruction. Again, I hoped that my students would be motivated to write about their findings and that in doing so they would better assimilate data interpretation.

At the start of class, I explained,

Today, we're going to translate our calculations into words so that we can make conclusions about the populations we surveyed.

I anticipated that this step would be the hardest because my students had demonstrated such difficulty with this skill during reading tasks. Before doing anything else, I distributed the worksheet that is shown in Figure 3 to assist them in developing some basic vocabulary.

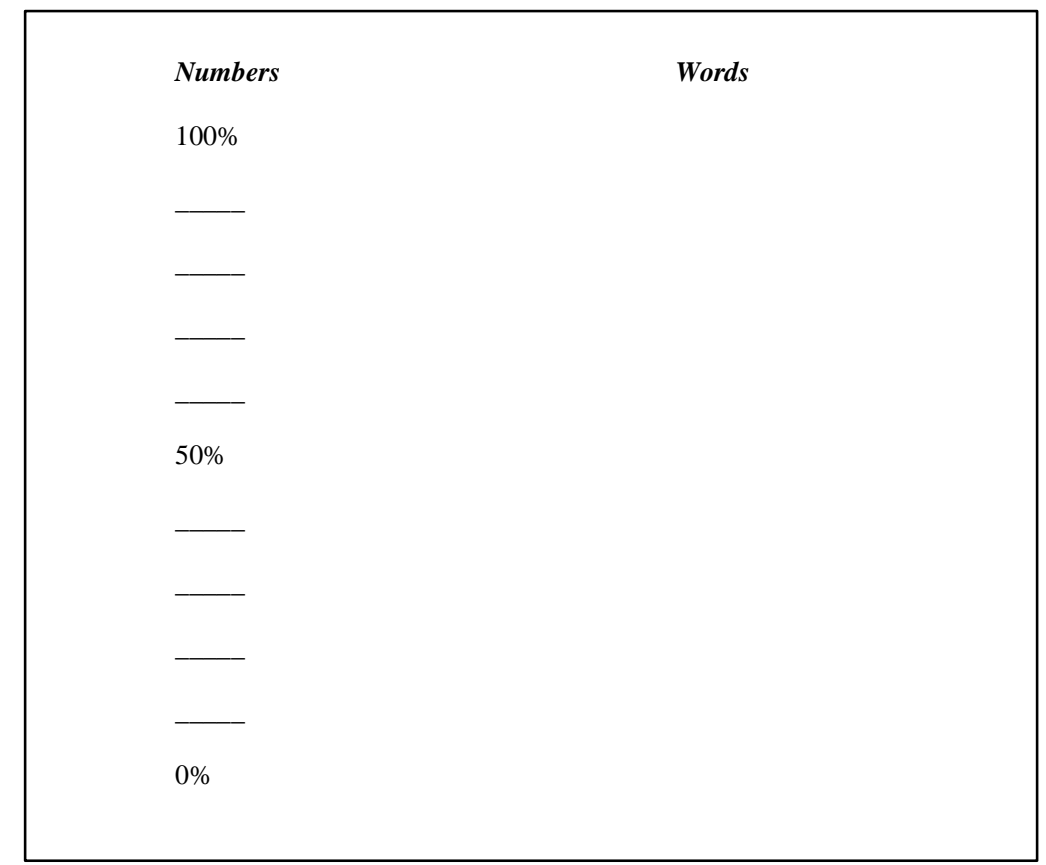

Figure 3. Translating percentages into words. Students used this sheet to help them analyze their data and write conclusion statements. They added percentages in increments of ten and recorded corresponding descriptors, such as "All," "Half," "A quarter," "Most," "Least," etc.

We started by filling in the missing percentages. Then, I asked students, "Who can tell me a word that means the same as "zero percent'?" My students responded "none" or "nothing." I asked, "What does 100\% mean" and they replied 
"all" or "everything." We continued in this fashion adding, "half," "a quarter," "three quarters," "most," "least," "majority," and "minority" to our worksheets.

Students then used their completed worksheets as scaffolds to assist them in making inferences about their results. They recorded their inferences in their writers' notebooks and looked for patterns to create a thesis that would summarize their findings and focus their presentation. For instance, after finding that considerably more female students than male students wish to attend college, and that most females and males want to play a sport in college, a student concluded, "Although more females plan to attend college than males, their opinions about living situations and campus involvement are similar." She then determined which of her findings supported her thesis and translated them into words as well.

After students finished writing about their findings, they created presentations, using Google Slides to display them. On the first slide, they wrote their thesis statements which summarized and unified their findings. On each proceeding slide, they wrote conclusions that supported their thesis. To provide evidence for each of their conclusions, they added mathematical representations such as graphs, tables, and pie charts. To do this, they used the National Center for Education Statistics's online Kids' Zone Create a Graph. ${ }^{1}$ They copied graphs directly from the website and pasted them into their presentations. Figures 4-6 display completed slides.

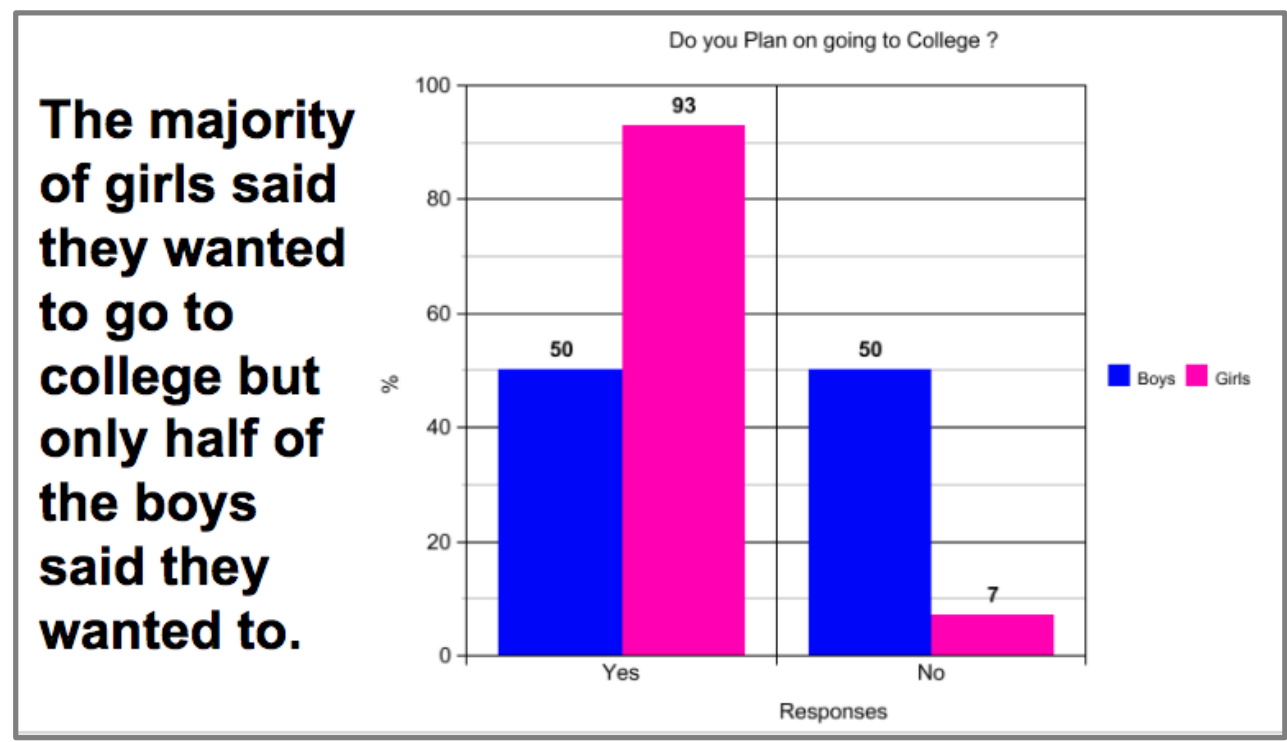

Figure 4. Completed presentation slide. Students used Google Slides to display their findings. Each slide included a conclusion statement and evidence to support it. The evidence used in this slide is a graph created using the National Center for Education Statistics" "Create a Graph."

\footnotetext{
${ }^{1}$ https://nces.ed.gov/nceskids/createagraph/
} 


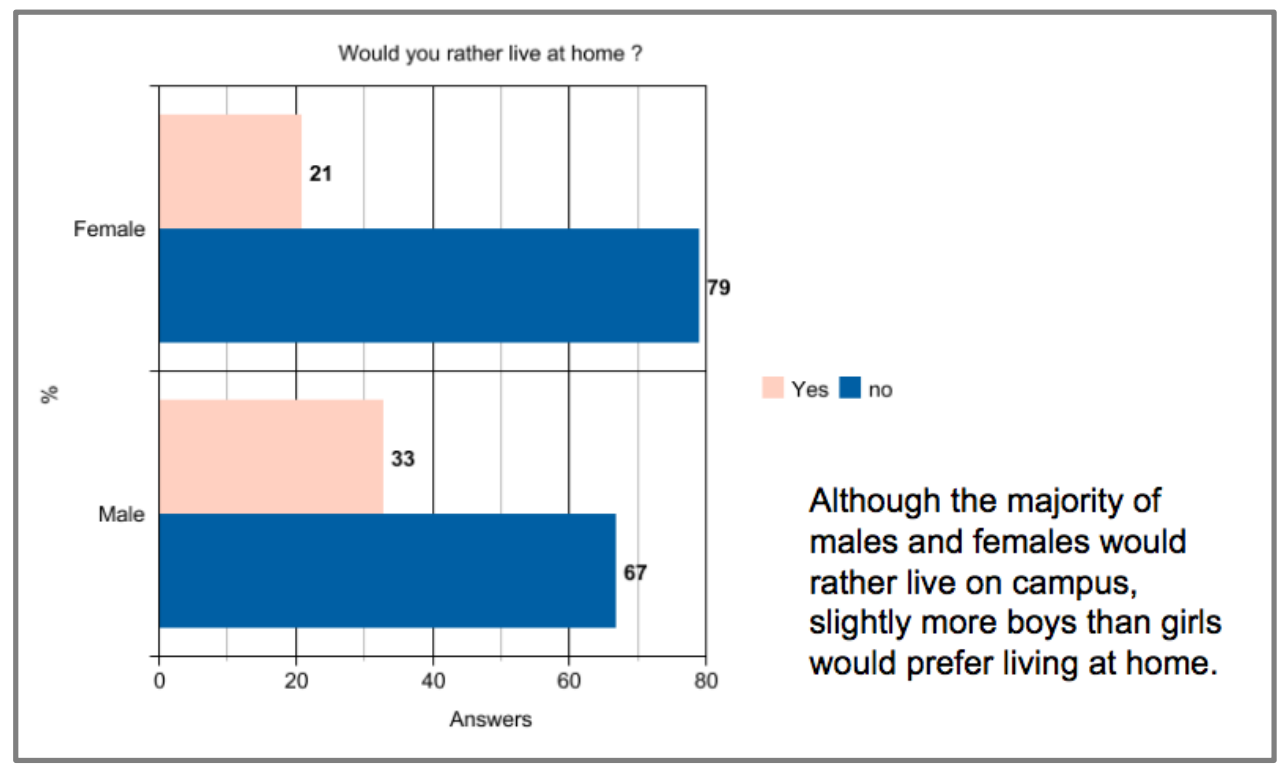

Figure 5. Completed presentation slide. This slide displays a student's survey question, the responses represented by a bar graph, and a conclusion statement.

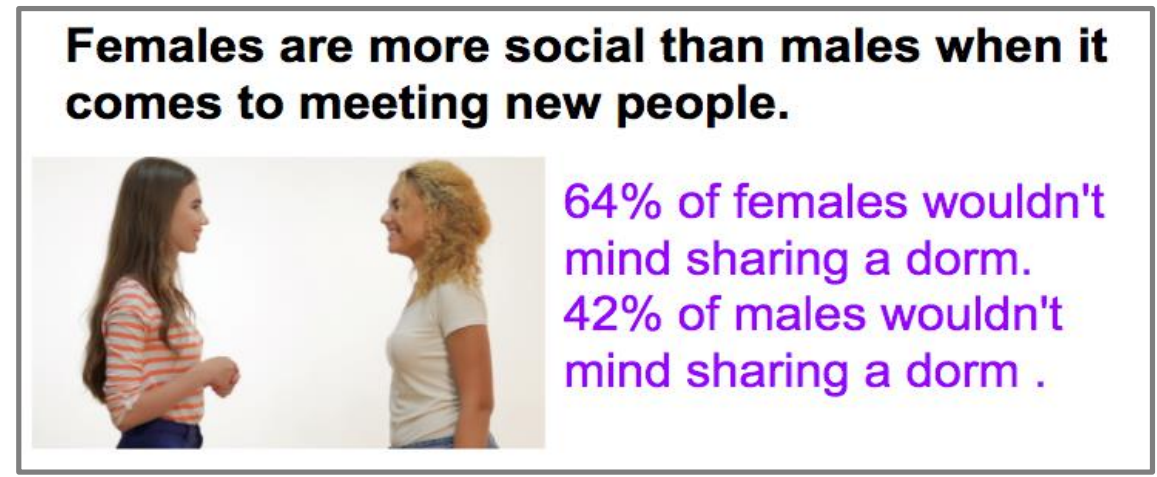

Figure 6. Completed presentation slide. This slide presents the survey question, responses represented by percentages, and a picture for illustration purposes.

\section{Class 6: Presenting Findings}

On the $7^{\text {th }}$ and final day of the unit, I proclaimed,

This is it! Today we will finally share our findings with each other and learn about what has kept our classmates so busy. 
Students took turns sharing their presentations. This required them to speak about the data they had calculated and to defend their interpretations of it. Some students shared conclusions that were still quite literal while others were deep and complex. Still, most were proud to share the results of their investigation.

\section{After the Inquiry-Survey Project}

Following the Inquiry-Survey Project, we moved onto a new unit in which students' strengthened understandings of data could be applied. Like the Inquiry-Survey Project, the next unit was project-based. In partners, students picked controversial topics such as abortion, raising the minimum wage, and legalizing marijuana. Rather than working together, partners worked against each other to create the more persuasive argument. To do so, they spent class time researching their topic and creating a presentation to argue their side of the issue. On presentation day, the rest of the class listened to their peers' presentations of both sides and voted on the one that was most convincing.

Students quickly learned that claims supported by data were stronger. When a presenter made a claim that appeared to be unfounded, their peers often demanded evidence, favoring data over narrative or anecdote.

\section{Concluding Thoughts}

Although interpreting mathematical representations is rarely mentioned in the ELA curriculum, it is a strategy worth teaching if we are to expect students to read and comprehend expository texts. Skills such as these, which comprise QL, are not being taught in the mathematics classroom. In order for students to assimilate them in the context of reading, we as ELA educators must make it our responsibility to teach them. Research suggests that explicitly teaching data interpretation is not effective (Karazsia 2013). Instead, an active learning practice such as The InquirySurvey Project will engage students in a data set that is meaningful and contextualized (Karazsia 2013). Writing about their findings, the students will further concretize data, which otherwise appears to many students as abstract when encountered in text (Beins 1993). The broader goal of the project is to better prepare students to navigate our data-saturated society so that they can make informed decisions that will better their lives and the lives of those around them.

\section{References}

Atwell, Nancie. 2002. Lessons That Change Writers. Portsmouth, NH: Heineman. Beins, Bernard C. 1993. "Writing Assignments in Statistics Classes Encourage Students to Learn Interpretation.” Teaching of Psychology 20(3): 161-64. 
Cockroft, Wilfred H. 1982. Mathematics Counts: Report of the Committee of Inquiry into the Teaching of Mathematics in Schools. London: Her Majesty's Stationary Office.

Forman, Susan L. and Lynn Arthur Steen, 1999. Beyond Eighth Grade:

Functional Mathematics for Life and Work. Berkeley, CA: National Center for Research in Vocational Education.

Gardner, David P., Yvonne Y. W. Larsen, William Baker, Anne Campbell, and Emeral A. Crosby. 1983. A Nation at Risk: The Imperative for Educational Reform. Washington, DC: United States Department of Education.

Hughes Hallett, Deborah. 2003. "The Role of Mathematics Courses in the Development of Quantitative Literacy." In Quantitative Literacy: Why Numeracy Matters for Schools and Colleges, edited by Bernard L. Madison and Lynn Arthur Steen, 91-98. Princeton, NJ: The National Council on Education and the Disciplines.

Karaali, Gizem, Edwin H. Villafane Hernandez, and Jeremy A. Taylor. 2016. "What's in a Name? A Critical Review of Definitions of Quantitative Literacy, Numeracy, and Quantitative Reasoning." Numeracy 9(1): Article 2.

Karaszia, Bryan T. 2013. "Enhancing Table Interpretation Skills via Training in Table Creation." Teaching of Psychology 40(3): 208-11.

Lemke, Jay. 1998. "Multiplying Meaning: Visual and Verbal Semiotics in Scientific Text." In Reading Science: Critical and Functional Perspectives on Discourses of Science, edited by J.R. Martin and Robert Veel, 87-113. London: Routledge.

National Research Council. 1989. Everybody Counts: A Report to the Nation on the Future of Mathematics Education. Washington, DC: National Academy Press.

Schoenfeld, Alan H. 2001. "Reflections on an Impoverished Education." In Mathematics and Democracy: The Case for Quantitative Literacy, edited by Lynn Arthur Steen, 49-54. Princeton, NJ: National Council on Education and the Disciplines.

Shreiner, Tamara L. 2017. "Data Literacy for Social Studies: Examining the Role of Data Visualizations in K-12 Textbooks." Theory \& Research in Social Educ 45(1): 1-38. https://doi.org/10.1080/00933104.2017.1400483.

Steen, Lynn Arthur. 1999. "Numeracy: The New Literacy for a Data-drenched Society." Educational Leadership 57(2): 8-13.

Steen, Lynn Arthur ed. 2001. Mathematics and Democracy: The Case for Quantitative Literacy. Princeton, NJ: The National Council on Education and the Disciplines.

Steen, Lynn Arthur. 2004. Achieving Quantitative Literacy: An Urgent Challenge for Higher Education. Washington, DC: Mathematical Association of America, 
Wiest, Lynda R., Heidi J. Higgins, and Janet Hart. 2007. "Quantitative Literacy for Social Justice.” Equity \& Excellence in Education 40(1): 47-55.

Wilkins, Jesse L. 2000. "Preparing for the $21^{\text {st }}$ Century: The Status of Quantitative Literacy in the United States." School Science and Mathematics 100(8): 405-18. 